\title{
Development of Critical Thinking in Doctoral Students in Education
}

\author{
Luis Alberto Nunez Lira ${ }^{1}$, Yolanda Felicitas Soria Perez ${ }^{2}$, Jesus Daniel Collanque Pinto ${ }^{3} \&$ Oriana Rivera-Lozada $^{3}$ \\ ${ }^{1}$ Universidad Nacional Mayor de San Marcos, Lima, Perú \\ ${ }^{2}$ Universidad César Vallejo, Lima, Perú \\ ${ }^{3}$ Universidad Privada Norbert Wiener, Lima, Perú \\ Correspondence: Luis Alberto Nunez Lira, Universidad Nacional Mayor de San Marcos, Lima, Perú.
}

Received: August 20, 2020

Accepted: October 15, 2020

Online Published: November 2, 2020

doi:10.5430/ijhe.v9n9p71

URL: https://doi.org/10.5430/ijhe.v9n9p71

\begin{abstract}
Critical thinking in university studies is the cornerstone for the development of research processes at the doctoral level; it becomes the vector of this action, whose processes in the management of learning will require that the competencies understood are developed by teachers and students, for the achievement of the goals proposed by the actors involved. This is how the research had the purpose of measuring the critical thinking of university doctorate students whose methodology was quantitative, with a population of 150 students, which allowed, in the first place, to establish the reliability and the analysis of the construct of the instrument used (Watson-Glaser test) and whose results showed a reliability of $0.77, \mathrm{KMO}$ of 0.757 with a bilateral significance of 0.000 . Likewise, of the five dimensions or factors of the instrument, five have a positive impact on moderate levels (Nagelkerke's pseudo- $\mathrm{R}$ square of 0.574 ) excluding inference. The descriptive analysis established that $11.3 \%$ present critical thinking at the advanced level.
\end{abstract}

Keywords: critical thinking, research, education, reasoning, academic management

\section{Introduction}

The university formation had a deep change from its law promulgated in July 2014. Until then, professional training was focused on traditional and behavioral models in most cases. The new paradigm oriented towards training by skills and research has been demanding greater academic and scientific rigor from teachers and students and, therefore, requires them to develop more critical thinking skills and attitudes.

However, the lack of information about their development makes their measurement and evaluation complex and makes it difficult to improve the formation of the student, at the height of modern social demands, even more so if it has been shown that the majority of university students come from a basic education of very low level.

University studies require selecting, organizing, analyzing and evaluating the various sources of information; cognitive skills are tested on students and teachers, and this has an impact on innovation, research and development of knowledge. Learning to think (learn-teach) in a reflective and critical way today is the key to facing the globalized world. Previous works related to the university field ratify that the above is key for the development of thought, professionalism and research; however, it presents a variety of instruments for its measurement that has generated controversy and has not allowed a complete understanding nor an adequate evaluation; the current search lies in establishing a model for its measurement (Ossa-Cornejo C., Palma-Luengo, Lagos-San Martín, \& Díaz-Larenas, 2018).

In evaluations carried out in the Universidad del Bio-Bio, Chile, using the test tasks of critical thinking (TPC), it was demonstrated the reliability of the instrument and that it has allowed the development of the scientific thought in students of the Faculty of Education (Ossa-Cornejo C., Palma-Luengo, Lagos-San Martín, \& Díaz-Larenas, 2018). And accompanied by the reading process, it will allow a professional development that enables the students to face the challenges of the modern globalized society without difficulties; their capacities will allow them to search for arguments and make relevant decisions in a critical way, with the enjoyment and analysis for the creative solution of problems (Flores Guerrero, 2016).

In quantitative studies of law students at the Universidad del Norte, Chile, the low levels of the various components analyzed for the development of critical thinking in solving problems typical of their profession and the social sciences were demonstrated (Betancourth-Zambrano, Muñoz-Morán, \& Rosas-Lagos, Evaluation of critical thinking 
in higher education students in the Atacama-Chile region, 2017). Likewise, in social work students, it was determined that $45 \%$ present advanced levels; $25 \%$, intermediate levels, and $30 \%$, very low. In addition, those coming from public educational institutions have better critical thinking (Betancourth-Zambrano, Martínez-Daza, \& Tabares-Díaz, Evaluation of critical thinking in social work students in the Atacama-Chile region, 2020).

In Colombia, in studies referred to the study variable and through qualitative-phenomenological studies, we seek to characterize critical thinking through images whose results indicate that $66 \%$ identify and recognize information, of which $62 \%$ have not established conclusions from the analysis of the images (Fajardo Pascagaza \& Castellanos Avellaneda, 2020).

With reference to critical thinking, many researchers suggest that educational institutions have a mission to develop autonomous thinking in students (López Aymes, 2012). But these changes in the curriculum imply breaking the old paradigms with which education has been carried out: it implies the introduction in management and decision making of the participation of educational actors for the dominant economic sectors, which is questioned by some. In these times, the single book, the same curriculum, is still imposed as if the country were socially and culturally homogeneous.

Despite the efforts of the educational sectors of critical and creative thinking, traditionalist models in education are maintained, where verticalism and authoritarianism continue to generate confusing processes in institutional and classroom management. Educational processes centered on content and results are being generated, and are notoriously reflected in the classrooms of doctoral studies, waiting for a professorship similar to their professional practice.

However, the conduct of learning requires that teachers, in addition to being critical thinkers, develop a set of skills that allow them to select, organize and synthesize knowledge and allow them to make inferences and make prospective decisions (Aznar Díaz, Cáceres Reche, \& Hinojo Lucena, 2011).

Critical thinking is conceived as a person's rationality and reflection to think and proceed. In addition, it can include the development of metacognitive skills (Kuhn \& Weinstock, 2002) and epistemological assessment for a better understanding of social facts and phenomena (Medina Peña, Medina de la Rosa, \& Moreno Montañez, 2017). It can also be understood as "specific judgment based on the reflection made through the perception of a certain observed or experienced phenomenon" (Luís Wafunga, Rodríguez García, \& Fuentes Cabrera, 2018).

"According to Chaffee 1994, the professor must always act as a thinking human being, as an intellectual, and not as a mere executor of tasks" (Luís Wafunga, Rodríguez García, \& Fuentes Cabrera, 2018). In other words, the teacher must have a set of tools that allow him/her to develop critical and reflexive thinking and, likewise, the student must be motivated to use them and to develop other tools (creativity).

In order to develop critical thinking, it is necessary to stimulate and strengthen reflection that allows the student to interact with the phenomenon or social fact and to put into play his or her cognitive competencies in a holistic way, for its understanding. Undoubtedly, the use of information technologies is fundamental for the development of thought, as it offers updated and high-level information producing positive effects on learning (Aznar Díaz, Cáceres Reche, \& Romero Rodríguez, 2018).

It also considers what Dewey (1998) states, where reflection constitutes an active and careful evaluation of all supposed knowledge about a fact or phenomenon with a rational and empirical consistency. This is because to develop this type of thinking is to focus on research, evaluation of the data obtained, thus explaining the judgment with a critical and contextualized basis (Lipman, 2016), logic and rationality that seeks to solve problems (Lara-Barragán Gómez \& Cerpa Cortés, 2014). Thus, the development of mental activity is the product of personal effort whose intervening capacities are memory, attention, understanding and learning (Rendón, Cuadros, Parra, \& Barragán, 2009).

Hence, it is important that learning management is focused on the development of critical thinking and enables the development of students' research profiles and increases criticality in the face of facts and phenomena. Learning to think critically implies the use of various mental processes to perform analysis-evaluation, such as categorization, selection, value judgments, application, in addition to interpreting, inferring and explaining (Facione, 2007).

Hence, this development implies a cognitive skill (Barnett, 1997) and that people can acquire it at different levels and whose characteristic is self-directed/corrective/monitored, which allows the person to participate in the activities and exercise his or her skills voluntarily (Paul \& Elder, 2003); that is, it depends on the student's responsibility to progress (Nosich, 2003) and these elements will positively influence critical thinking (Halpern, 1998). 
For the evaluation of critical thinking, the Watson-Glaser test has been used, which considers it as "a mixture of attitudes, knowledge and skills. It includes: (1) attitudes of inquiry, an ability to recognize the existence of problems, and an acceptance of the general need for evidence to support claims; (2) knowledge of the nature of valid inferences, captures, and generalizations in which the weight or accuracy of different types of evidence are logically determined; and (3) skills in employing and applying the attitudes and knowledge mentioned above" (Watson \& Glaser, 1980).

It is oriented to the reflexive thought that implies - to interpret, to identify, to analyze and to evaluate - the evaluation of the deductions and inferences. It is conformed by 80 items, in five dimensions that are the following: inference, recognition, deduction, interpretation and evaluation of arguments (Da Dalt de Mangione \& Difabio de Anglat, 2007).

The Watson \& Glaser instrument presents five dimensions to measure critical thinking: inference, which allows the discrimination of the phenomena observed through five alternatives per question (valid/probably-valid/data-insufficient/probably-invalid/invalid); recognition of statements (Yes-fact-not done); deduction (yes-followed and no-followed), interpretation that judges a generalization (yes-no) and evaluation of the argument (yes-no).

Inference is defined as the product of the evaluation of the facts or phenomena under study, and it allows us to obtain reasoned results and at the same time to make conjectures that allow us to predict their course. The recognition of assumptions is to take for granted a statement or premise formulated with the aim of establishing associations between the descriptors or questions, where the researcher expresses his or her opinion. Deduction allows for the association of proposals and conclusions about an investigation for relevant and appropriate decision making. The interpretation allows the evaluation and discrimination of the findings or evidence, which leads to the understanding of the fact, and that in the investigation, allows the respective categorizations. The evaluation of arguments allows us to determine the importance of the fact, to value them, with logical argumentation of the associations produced in a phenomenon (Watson \& Glaser, 1980).

\section{Methodology}

The methodology that has been used is quantitative and basic, substantive because it has updated the knowledge of the variable under study with new findings (Bernal, 2010) and is explanatory because it has sought the causes that generate the phenomenon (Hernández \& Mendoza, 2018), ie, the factors that have determined that students have achieved critical thinking.

Likewise, the research design used was non-experimental and cross-sectional, collecting the information at a given time and where the study variable has not been manipulated (Ander Egg, 2011).

The critical thinking variable proposed by Watson \& Glaser presents five factors or dimensions, where each one of them presents indicators and 80 reagents or questions, whose measurement scale is: in dimension 1 inference 1 is PV, PI; ID; I; V, dimension 2, "Yes done (2) Not done (1)"; dimension 3 and dimension 4: Yes followed (2) Not followed (1); and dimension 5 Yes (2) Not (1).

Table 1. Operationalization matrix of the critical thinking variable

\begin{tabular}{|c|c|c|c|}
\hline Dimension & Indicators & Ítems & Measurement scale \\
\hline \multirow{3}{*}{ Inference } & Evaluate & \multirow{3}{*}{1 to16 } & \multirow{3}{*}{ PV, PI; ID; I; V } \\
\hline & Deduce & & \\
\hline & Concludes & & \\
\hline \multirow{2}{*}{ Recognition of assumptions } & Distinguish & \multirow{2}{*}{17 to 32} & Yes done (2) \\
\hline & Recognize & & Not done (1); \\
\hline \multirow{2}{*}{ Deduction } & Link to & \multirow{2}{*}{33 to 48} & \multirow{2}{*}{ Yes followed (2) Not followed (1) } \\
\hline & Determine & & \\
\hline \multirow{3}{*}{ Interpretation } & Rate & \multirow{3}{*}{49 to 64} & \multirow{3}{*}{ Yes followed (2) Not followed (1) } \\
\hline & Discriminate & & \\
\hline & Judge & & \\
\hline \multirow{2}{*}{ Argument Evaluation } & Differentiate & \multirow{2}{*}{65 to 80} & Yes (2) \\
\hline & Sort & & No (1) \\
\hline
\end{tabular}


The population is considered to be all the elements whose characteristics are similar and allow the analysis (Hernández \& Mendoza, 2018). The population considered for the study is 150 graduate students whose sample for the study will be the entire population, so it is considered a census (Bernal, 2010).

The technique used was the survey, using the Google form; this procedure is relevant for the collection of information due to the situation of the health emergency.

The instrument applied was a questionnaire (Watson-Glaser test) whose reliability (Kuder Richarson) presented the following results: test 0.77 ; dimension 1: 0.782 ; dimension 2: 0.776; dimension 3: 0.801 ; dimension 4: 0.835 and dimension 5: 0.74

The instrument's construct analysis at an exploratory level was made to the test and its dimensions, considering the capacities and questionnaires used, whose results indicated us that the KMO and Bartlett test is for PC (.757), I (.556) RS (.749), D (.766), In (.855) and EA (.657), whose chi-square and bilateral significance is PC (7716,048); $0.000)$ I $(843,380 ; 0.000)$, RS $(1509,391 ; 0.000)$, D (1509,391; 0.000), In $(1189,338 ; 0.000)$ and EA $(410,396 ; 0.000)$ which reject the hypothesis that the variables are associated.

Table 2. Barlett's sphericity test

\begin{tabular}{|c|c|c|c|c|c|c|c|}
\hline \multicolumn{2}{|l|}{ KMO and Bartlett test } & $\begin{array}{l}\text { Critical } \\
\text { thinking (CP) }\end{array}$ & $\begin{array}{l}\text { Inference } \\
\text { (I) }\end{array}$ & $\begin{array}{l}\text { Recognition of } \\
\text { assumptions } \\
\text { (RS) }\end{array}$ & $\begin{array}{l}\text { Deduction } \\
\text { (D) }\end{array}$ & $\begin{array}{l}\text { Interpretation } \\
\text { (In) }\end{array}$ & $\begin{array}{l}\text { Evaluation of } \\
\text { arguments (EA) }\end{array}$ \\
\hline \multicolumn{2}{|l|}{$\begin{array}{l}\text { Kaiser-Meyer-Olkin } \\
\text { measurement of sampling } \\
\text { adequacy }\end{array}$} &, 757 &, 556 & ,749 & 0,766 &, 855 & ,657 \\
\hline \multirow[t]{3}{*}{$\begin{array}{l}\text { Bartlett } \\
\text { Sphericity } \\
\text { Test }\end{array}$} & $\begin{array}{l}\text { Aprox. } \\
\text { Chi- } \\
\text { square }\end{array}$ & 7716,048 & 843,380 & 1509,391 & 1509,391 & 1189,338 & 410,396 \\
\hline & $\mathrm{gl}$ & 3160 & 120 & 120 & 120 & 136 & 120 \\
\hline & Sig. & ,000 & ,000 & ,000 & ,000 & ,000 & 000 \\
\hline
\end{tabular}

The factor extraction analysis was performed to the test and to the five dimensions with auto-values of 0.40 , whose data explanation is higher than $42.753 \%$ in PC test, $49.965 \%$ in I, $60.403 \%$ in RS, $69.044 \&$ in D, $62.150 \%$ in In and $46.615 \%$ in $\mathrm{AE}$.

Table 3. Value extraction method

\begin{tabular}{|c|c|c|c|c|c|c|c|c|c|c|c|c|}
\hline \multirow[b]{2}{*}{ Com } & \multicolumn{2}{|c|}{$\begin{array}{l}\text { Critical thinking } \\
\text { (CP) }\end{array}$} & \multicolumn{2}{|c|}{ Inference (I) } & \multicolumn{2}{|c|}{$\begin{array}{l}\text { Recognition of } \\
\text { assumptions } \\
\text { (RS) }\end{array}$} & \multicolumn{2}{|c|}{ Deduction (D) } & \multicolumn{2}{|c|}{$\begin{array}{l}\text { Interpretation } \\
\text { (In) }\end{array}$} & \multicolumn{2}{|c|}{$\begin{array}{l}\text { Evaluation of } \\
\text { arguments } \\
\text { (EA) }\end{array}$} \\
\hline & Total : & $\begin{array}{c}\% \\
\text { accumul } \\
\text { ated }\end{array}$ & Total & $\begin{array}{c}\% \\
\text { accumu } \\
\text { lated }\end{array}$ & Total & $\begin{array}{c}\% \\
\text { accumu } \\
\text { lated }\end{array}$ & Total & $\begin{array}{c}\% \\
\text { acumul } \\
\text { ated }\end{array}$ & Total & $\begin{array}{c}\% \\
\text { acumul } \\
\text { ated }\end{array}$ & Total & $\begin{array}{c}\% \\
\text { acumul } \\
\text { ated }\end{array}$ \\
\hline 1 & 20,285 & 25,356 & 2,380 & 15,864 & 3,395 & 21,217 & 4,208 & 26,298 & 5,777 & 33,980 & 3,086 & 19,290 \\
\hline 2 & 5,693 & 32,472 & 2,043 & 29,481 & 3,022 & 40,107 & 3,254 & 46,635 & 2,184 & 46,829 & 1,756 & 30,266 \\
\hline 3 & 4,945 & 38,653 & 1,733 & 341,035 & 2,055 & 52,950 & 2,261 & 60,765 & 1,512 & 55,723 & 1,344 & 38,665 \\
\hline 4 & 3,280 & 42,753 & 1,339 & 49,965 & 1,192 & 60,403 & 1,325 & 69,044 & 1,093 & 62,150 & 1,272 & 46,615 \\
\hline 5 & 2,451 & 45,817 & 1,166 & $5 \quad 57,736$ & 0,953 & 66,360 & 1,113 & 76,000 & 0,970 & 67,854 & 1,151 & 53,809 \\
\hline 6 & 2,311 & 48,705 & & & & & & & & & & \\
\hline n & & & & & & & & & & & & \\
\hline
\end{tabular}


Likewise, for the data procedure these were tabulated in Excel 2019 tables and absolute and relative frequencies were established: in addition, the information was processed in SPSS-26; the hypothesis was contrasted through factor analysis with the multivariate logistic regression test that determined the levels of influence of the components.

Finally, the instruments applied had the informed consent and the PLA norms were used, respecting the authorship in the referenced works for the argumentation and demonstration of research.

\section{Results}

The descriptive analysis of the survey applied to doctoral students established that $11.3 \%$ present critical thinking at the advanced level; $88.0 \%$, intermediate level and $0.7 \%$, basic level. In the inference dimension, $32.7 \%$ present advanced level; $58.0 \%$, intermediate level and $9.3 \%$, basic level. In the assumption recognition dimension, $48.0 \%$ are at the advanced level, $48.0 \%$ at the intermediate level and $4.0 \%$ at the basic level. In the dimension of deduction, $26.7 \%$ have an advanced level, $65.3 \%$ an intermediate level and $8.0 \%$ a basic level. In the interpretation dimension, $64.7 \%$ are at an advanced level, $22.7 \%$ at an intermediate level and $12.7 \%$ at a basic level. In the evaluation of arguments dimension, $71.3 \%$ present an advanced level; 26.7\%, an intermediate level, and 2.0\%, a basic level.

Table 4. Descriptive analysis of the critical thinking variable

\begin{tabular}{|c|c|c|c|c|c|c|c|c|c|c|c|}
\hline \multirow[b]{3}{*}{ Level } & \multirow{2}{*}{\multicolumn{2}{|c|}{$\begin{array}{l}\text { Critical } \\
\text { thinking }\end{array}$}} & \multicolumn{9}{|c|}{ Dimensions } \\
\hline & & & \multicolumn{2}{|c|}{ Inference } & \multicolumn{2}{|c|}{$\begin{array}{l}\text { Recognition of } \\
\text { assumptions }\end{array}$} & \multicolumn{2}{|c|}{ Deduction } & \multicolumn{2}{|c|}{ Interpretation } & \multirow{2}{*}{$\begin{array}{l}\begin{array}{l}\text { Evaluation of } \\
\text { arguments }\end{array} \\
\mathrm{f}\end{array}$} \\
\hline & $\mathrm{f}$ & $\%$ & $\mathrm{f}$ & $\%$ & $\mathrm{f}$ & $\%$ & $\mathrm{f}$ & $\%$ & $\mathrm{f}$ & $\%$ & \\
\hline Advanced & $\overline{17}$ & 11,3 & 49 & 32,7 & 72 & 48,0 & 40 & 26,7 & 97 & 64,7 & 107 \\
\hline Intermediate & 132 & 88,0 & 87 & 58,0 & 72 & 48,0 & 98 & 65,3 & 34 & 22,7 & 40 \\
\hline Basic & 1 & 0,7 & 14 & 9,3 & 6 & 4,0 & 12 & 8,0 & 19 & 12,7 & 3 \\
\hline Total & 150 & $100 \%$ & 150 & $100 \%$ & 150 & $100 \%$ & 150 & $100 \%$ & 150 & $100 \%$ & 150 \\
\hline
\end{tabular}

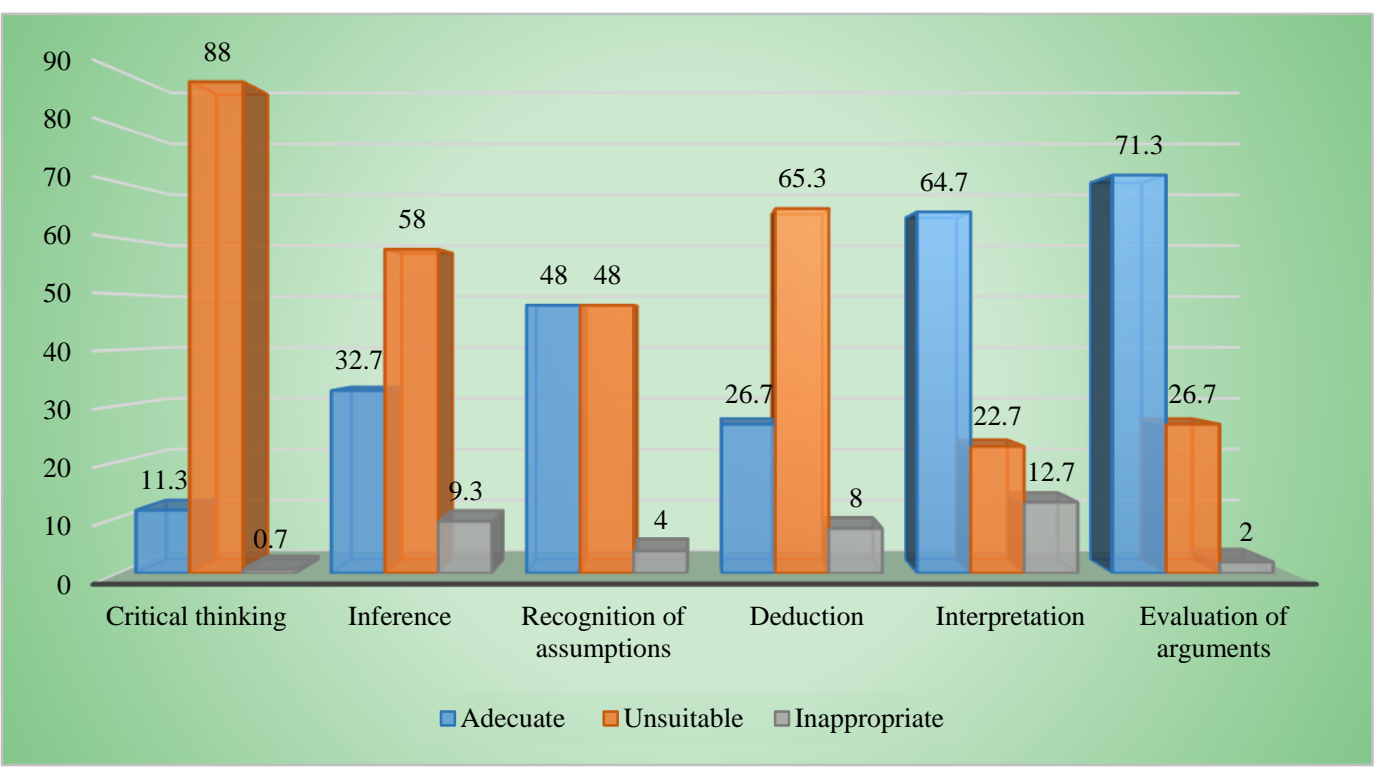

Figure 1. Descriptive analysis of the critical thinking variable

With reference to the general hypothesis, the determining factor is critical thinking, there are four with Nagelkerke's pseudo R-square index of 0.574 , that is $57.4 \%$ of the data in recognition of assumptions (bilateral sig. of ,005), deduction (bilateral sig. of ,000), interpretation (bilateral sig. of ,027) and evaluation of arguments (bilateral sig. of ,034), this influence being only at the advanced level. 
In the specific hypotheses the indicator of the inference dimension is three with the index of Nagelkerke's pseudo- $R$ square of 0.795 , that is $79.5 \%$ of the data in evaluates (sig. bilateral of ,000) and deduces (sig. bilateral of ,000) in the advanced level and concludes (sig. bilateral ,001) in the basic level. The indicator of the dimension recognition of assumptions is two with the Nagelkerke's pseudo R-square index of 0.832 , that is $83.2 \%$ of the data in recognition (sig. bilateral of ,000) at the advanced level. The indicator of the dimension deduction is two with the Nagelkerke's pseudo-R square index of 0.856 , that is $85.6 \%$ of the data to be determined (sig. bilateral of, 000 ) in the advanced level.

The indicator of the interpretation dimension is two with the Nagelkerke's pseudo-R square index of 0.856 , that is $85.6 \%$ of the data to be discriminated (sig. bilateral of ,000) in the advanced level and the indicator of the evaluation of results dimension is two with the Nagelkerke's pseudo-R square index of 0.617 , that is $61.7 \%$ of the data, in difference (sig. bilateral of ,000) and classified (sig. bilateral of ,000) in the advanced level.

Table 5. General and specific hypothesis testing

\begin{tabular}{|c|c|c|c|c|c|c|}
\hline & \multirow{2}{*}{ Hypothesis system } & \multicolumn{2}{|c|}{ Model Fitting Information } & \multirow{2}{*}{$\begin{array}{l}\text { Pseudo R } \\
\text { square } \\
\text { Nagelkerke }\end{array}$} & \multirow{2}{*}{$\begin{array}{l}\text { Level of } \\
\text { influence } \\
\text { Nx100\% }\end{array}$} & \multirow{2}{*}{$\begin{array}{c}\text { Parameter } \\
\text { estimates }\end{array}$} \\
\hline & & $\begin{array}{c}\text { Logarithm of } \\
\text { verisimilitude -2 }\end{array}$ & Sig. & & & \\
\hline \multirow{5}{*}{ 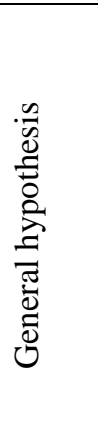 } & \multirow{5}{*}{$\begin{array}{l}\text { At least one factor } \\
\text { positively influences } \\
\text { the critical thinking of } \\
\text { doctoral students }\end{array}$} & \multirow{5}{*}{18,825} & \multirow{5}{*}{, 000} & \multirow{5}{*}{, 574} & \multirow{5}{*}{$57,4 \%$} & Advanced level \\
\hline & & & & & & $\begin{array}{l}\text { Recognition of } \\
\text { Assumptions } \\
(, 0005)\end{array}$ \\
\hline & & & & & & Deduction $(, 000)$ \\
\hline & & & & & & $\begin{array}{l}\text { Interpretation } \\
(0,027)\end{array}$ \\
\hline & & & & & & $\begin{array}{l}\text { Evaluation of } \\
\text { arguments } \\
(0,034)\end{array}$ \\
\hline \multirow{5}{*}{ 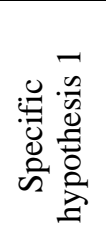 } & \multirow{5}{*}{$\begin{array}{l}\text { At least one indicator } \\
\text { positively influences } \\
\text { the inference dimension } \\
\text { in doctoral students }\end{array}$} & \multirow{5}{*}{14,219} & \multirow{5}{*}{,000 } & \multirow{5}{*}{,795 } & \multirow{5}{*}{79,55} & Advanced level \\
\hline & & & & & & Evaluate $(, 000)$ \\
\hline & & & & & & Deduct $(, 000)$ \\
\hline & & & & & & Basic Level \\
\hline & & & & & & Concludes $(, 001)$ \\
\hline 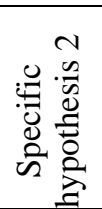 & $\begin{array}{l}\text { At least one indicator } \\
\text { positively influences } \\
\text { the recognition of } \\
\text { assumptions dimension } \\
\text { in doctoral students }\end{array}$ & 8,024 & ,000 & ,832 & $83,2 \%$ & $\begin{array}{l}\text { Advanced level } \\
\text { Recognize }(, 000)\end{array}$ \\
\hline 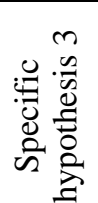 & $\begin{array}{l}\text { At least one indicator } \\
\text { positively influences } \\
\text { the deduction } \\
\text { dimension in doctoral } \\
\text { students }\end{array}$ & 10,239 & ,000 & ,856 & $85,6 \%$ & $\begin{array}{l}\text { Advanced level } \\
\text { Determine }(, 000)\end{array}$ \\
\hline 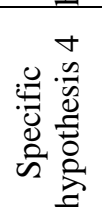 & $\begin{array}{l}\text { At least one indicator } \\
\text { positively influences } \\
\text { the interpretation } \\
\text { dimension in doctoral } \\
\text { students }\end{array}$ & 10,338 & ,000 & ,800 & $80,0 \%$ & $\begin{array}{l}\text { Advanced level } \\
\text { Discriminate } \\
(, 000)\end{array}$ \\
\hline 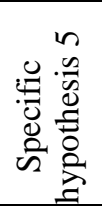 & $\begin{array}{l}\text { At least one indicator } \\
\text { positively influences } \\
\text { the evaluation } \\
\text { dimension of arguments } \\
\text { in doctoral students }\end{array}$ & 22,039 & ,000 & 617 & $61,7 \%$ & $\begin{array}{l}\text { Differentiate } \\
(, 000) \\
\text { Sort }(, 000)\end{array}$ \\
\hline
\end{tabular}




\section{Discussion}

The applied reliability analysis (Kuder Richarson) was consistent with Da Dalt by Mangione \& Difabio by Anglat (2007) presenting 0.77 (0.82) for the test; and for the inference dimensions $0.782(0.66)$; recognition of assumptions 0.776 (0.61); deduction $0.801(0.48)$; interpretation 0.835 (0.55) and evaluation of arguments $0.74(0.7)$, considering that a sample of 150 and Da Dalt Mangiones et al. 102 students.

The analysis of construct the results obtained with the test of KMO and Bartlett is for PC (.757), I (.556) RS (.749), D (.766), In (.855) and EA (.657), whose chi square and bilateral significance is PC $(7716,048 ; 0,000)$ I $(843,380$; $0,000)$, RS (1509,391; 0,000), D (1509,391); 0.000), In (1189,338;0.000) and EA (410,396; 0.000) demonstrating the association of variables and is similar to the findings of Da Dalt by Mangione \& Difabio by Anglat (2007) with self values of 0.35 , which explain the $52.26 \%$ that also demonstrate the association of variables.

The descriptive results indicated us relevant information about the level in which the doctorate students are, where most of them present critical thinking and a reduced number are in basic levels, standing out that of the five dimensions proposed by Watson \& Glaser, four of them have more influence for this determination (less the inference) but only this is done when the students reach the advanced level. The findings of Ossa-Cornejo C. J., Palma-Luengo, Lagos-San Martín, Quintana-Abello, \& Díaz-Larenas (2017) explain the importance of critical thinking that allows us to fully understand this assessment, establishing a key model to measure it, being Watson \& Glaser's the pertinent one to do it and considering the need to permanently adapt it according to the contexts of its application.

In evaluations carried out in two faculties of the Universidad del Bio-Bio, Chile, it was also demonstrated the reliability of the instrument and that it has allowed the evaluation of the PC in the students where the education instrument was applied (Ossa-Cornejo C., Palma-Luengo, Lagos-San Martín, \& Díaz-Larenas, 2018), whose results have allowed the taking of decisions to overcome the gap between the reality and the ideal, whose direct benefits will be in the students that will allow to confront successfully their formation and professional development (Flores Guerrero, 2016).

Also at the Universidad del Norte in Chile, this instrument was applied by finding low levels of PC in problem solving in the social sciences at the Law School (Betancourth-Zambrano, Muñoz-Morán, \& Rosas-Lagos, 2017), and $30 \%$ at very low levels (Betancourth-Zambrano, Martínez-Daza, \& Tabares-Díaz, 2020). This shows us the applicability of the instrument and its effectiveness in measuring PC, in different contexts.

Its application to institutions of higher education and even to those of basic education (adapting the instrument) is important because it is the mission of education today, breaking the old paradigms that subsist in the educational system, whose management of the pedagogical processes should establish the development of these skills for both teachers and students.

Therefore, in agreement with Aznar Díaz, Cáceres Reche, \& Hinojo Lucena (2011), the conduct of learning requires that teachers be, in addition to critical thinkers, that they develop skills that allow them to select, organize and synthesize knowledge and that allow them to make inferences and do prospective work, together with their students.

The specific results whose indicators have notoriously influenced the advanced levels of the PC, demonstrate the rationality, the reflection of the students, linking with the metacognitive competences (Kuhn \& Weinstock, 2002), generating in them the understanding of the fact or social phenomenon observed (Luís Wafunga, Rodríguez García, \& Fuentes Cabrera, 2018), but endowed with a set of didactic tools and motivation for their use.

With reference to the inference, two of the indicators have influenced this dimension notably (evaluate and deduce), but only in the advanced levels, which allows us to affirm that the evaluation of facts is reached by $11.3 \%$ of the students, because their results are the product of reasoning and they have been able to prevent their channeling.

The dimension recognition of assumptions, the indicator recognize, presents an influence of $83.2 \%$, but in advanced levels, demonstrating that this level is reached by $11.3 \%$ because they have been able to associate the descriptors and questions of the test. The dimension deduction, the indicator recognize, presents an influence of $85.6 \%$, but in advanced levels reached by $11.3 \%$, since they recognized the facts in the exercises posed.

The interpretation dimension, the discriminate indicator, presents an influence of $80.0 \%$, but in advanced levels reached by $11.3 \%$, since they were able to value and discriminate the findings in the exercises posed. The differentiate and classify indicators present an influence of $61.7 \%$, but in advanced levels reached by $11.3 \%$, because they valued with logical argumentation the associations produced in a phenomenon. 
For that reason, Aznar Díaz, Cáceres Reche, \& Romero Rodríguez (2018) affirm that it is necessary to stimulate and to strengthen reflection, whose interaction with the social facts allows the development of cognitive competitions, for a constant evaluation of the learned or developed knowledge on a social fact, with a solid argumentation (Dewey, 1998), where the teacher's role is fundamental in the process of learning management.

\section{Conclusions}

The findings show the level of $\mathrm{CP}$ in the students surveyed, whose frequency is overwhelmingly at the intermediate level and at an advanced level of $11.3 \%$, with the basic level being insignificant. These data allow establishing improvement strategies in learning management with the purpose of achieving relevant research and high academic level by the implementation of the promoted and acquired competences.

It has been demonstrated that of the five dimensions and twelve indicators evaluated through the test, the majority had a strong and positive influence in the advanced levels, leaving the mission to develop it in the intermediate levels where the majority of the students are found.

Therefore, the need for teachers to identify the ideal strategies to develop the PC, such as those suggested by various university pedagogues such as problem-based learning, Gowin's W, visual organizers among others and the appropriate use of various ICT technologies, with updated and indexed databases, guiding the efforts to generate learning and quality products in the doctoral programs.

The research carried out is a contribution to the evaluation of the PC in the development of learning, because it orients us to develop the educational quality, leaving open the possibility of other investigations linked them to determinant factors of PC, like associating it with the comprehension of texts, logical thought and to other domains of the knowledge or educational levels.

\section{References}

Ander Egg, E. (2011). Aprender a investigar: nociones básicas para la investigación social. Córdoba: Brujas.

Aznar Díaz, I., Cáceres Reche, M. P., \& Romero Rodríguez, J. M. (2018). Efecto de la metodología de aprendizaje de mobiels en la enseñanza universitaria: meta-análisis de la investigación publicada en WOS y Scopus. Risti: Revista Ibérica de Sistemas y Tecnologías de la Información, (30), 1-16. https://doi.org/10.17013/risti.30.1-16

Aznar Díaz, I., Cáceres Reche, M. P., \& e Hinojo Lucena, M. A. (2011). La adquisición de habilidades específicas en la educación superior. Evaluación de la formación del psicólogo educativo de la Universidad de Granada. Ensayos. Revista de la Facultad de Educación de Albacete, (26), 71-93.

Barnett, R. (1997). Higher Education: Un negocio crítico: La Sociedad para la Investigación de la Educación Superior. Milton Keynes: McGraw-Hill Education.

Bernal, C. A. (2010). Research Methodology ( $3^{\mathrm{a}}$ ed.). Bogotá D. C.: Pearson Education.

Betancourth-Zambrano, S., Martínez-Daza, V., \& Tabares-Díaz, Y. A. (2020). Evaluación del pensamiento crítico en estudiantes de trabajo social en la región de Atacama-Chile. Entramado, 16(1), 152-164. https://doi.org/10.18041/1900-3803/entramado.1.6139

Betancourth-Zambrano, S., Muñoz-Morán, K. T., \& Rosas-Lagos, T. J. (enero-junio de 2017). Evaluación del pensamiento crítico en estudiantes de educación superior en la región de Atacama-Chile. Prospectiva. Revista de trabajo social e intervención social, 23, 199-223. https://doi.org/10.25100/prts.v0i23.4594

Da Dalt de Mangione, E., \& Difabio de Anglat, H. (2007). Evaluación de la competencia crítica a través de la prueba Watson-Glaser. Exploración de sus cualidades psicométricas. Journal of Psychology, 3(6), 1-14.

Dewey, J. (1998). Cómo pensamos: nueva exposición de la relación entre el pensamiento reflexivo y el proceso educativo. (M. A. Galmarini, Trad.) Barcelona: Paidós.

Facione, P. A. (2007). Critical thinking: an expert consensus statement for evaluation and educational instruction purposes. Obtenido el 28 de septiembre de 2020, del sitio web Insight Assessment.

Fajardo Pascagaza, E., \& Castellanos Avellaneda, E. L. (2020). El pensamiento crítico y su impacto en la educación de las artes plásticas: el caso del IE Bojacá de Chía, Colombia. Signos, 41(1). http://doi.org/10.22410/issn.1983-0378.v41i1a2020.2570

Flores Guerrero, D. (enero-junio de 2016). La importancia y el impacto de la lectura, la escritura y el pensamiento crítico en la educación superior Zona Próxima. Revista del Instituto de Estudios de la Educación, Universidad del Norte, (24), 1-8. 
Halpern, D. (1998). Teaching critical thinking for transfer across domains: Disposición, habilidades, entrenamiento de estructuras y monitoreo metacognitivo. American Psychologist, 53(4), 449-455. https://doi.org/10.1037/0003-066X.53.4.449

Hernández, R., \& Mendoza, C. (2018). Metodología de investigación: las rutas cuantitativa, cualitativa y mixta. Ciudad de México: McGraw-Hill Education. https://doi.org/10.17993/CcyL1.2018.15

Kuhn, D., \& Weinstock, M. (2002). Qué es el pensamiento epistemológico y por qué es importante? En B. B. K. Hofer, \& P. Pintrich, Personal epistemology: La psicología de las creencias sobre el conocimiento y el saber (pp. 121-144). Lawrence Erlbaum Associates Publishers.

Lara-Barragán Gómez, A., \& Cerpa Cortés, G. (marzo de 2014). Enseñanza de la física y desarrollo del pensamiento crítico. Latin American Journal of Physics Education, 8(1), 52-59.

Lipman, M. (2016). El lugar del pensamiento en la educación. (M. Gómez Pérez, Trad.) Barcelona: Octaedro.

López Aymes, G. (2012). El pensamiento crítico en el aula. Docencia e investigación, XXXVII(22), 41-60.

Luis Wafunga, Â. A., Rodríguez García, A.-M., \& Fuentes Cabrera, A. (Junio 2018). Desarrollo del pensamiento crítico a través de la enseñanza de la historia en Benguela. Innoeduca. Revista Internacional de Tecnología e Innovación Educativa, 4(1), 88-94. http://doi.org/10.24310/innoeduca.2018.v4i1.2523

Medina Peña, R., Medina de la Rosa, R. E., \& Moreno Montañez, M. (mayo-julio de 2017). Pensamiento crítico y aprendizaje en grupo: una forma de mejorar la comunicación en los estudiantes universitarios. Universidad y Sociedad, 9(4), 168-176.

Nosich, G. M. (2003). Learning to think: analytical thinking for students (Aprender a pensar: pensamiento analítico para estudiantes). (J. L. Posadas, Ed., \& A. Martos, Trad.). Madrid: Pearson Educación S. A.

Ossa-Cornejo, C. J., Palma-Luengo, M. R., Lagos-San Martín, N., Quintana-Abello, I. M., \& Díaz-Larenas, C. H. (2017). Análisis de los instrumentos de medición del pensamiento crítico. Psychological Sciences, 11(1), 19-28. https://doi.org/10.22235/cp.v11i2.1343

Ossa-Cornejo, C., Palma-Luengo, M., Lagos-San Martín, N., \& Díaz-Larenas, C. (Mayo-Agosto 2018). Evaluación del pensamiento crítico y científico en estudiantes de pedagogía de una universidad chilena. Revista Electrónica Educare, 22(2), 1-18. https://doi.org/10.15359/ree.22-2.12

Paul, R., \& Elder, L. (2003). The mini-guide for critical thinking: concepts and tools. Obtenido el 28 de septiembre de 2020, de The Foundation for Critical Thinking.

Rendón, M., Cuadros, O., Parra, P., \& Barragán, B. (2009). Aprender a pensar socialmente. Programa de intervención pedagógica basado en las habilidades de pensamiento crítico y aprendizaje cooperativo para el desarrollo de la competencia socio-emocional en el contexto escolar. Medellín: Litoimpresos y Universidad de Antioquía.

Torres Merchán, N. Y., \& Solbes Matarredona, J. (2014). Aspectos convergentes del pensamiento crítico y cuestiones socio-científicas. Revista Gondola: Teaching and learning in science, 9(1), 54-61. https://doi.org/10.14483/23464712.7312

Watson, G., \& Glaser, E. (1980). Critical Thinking Appraisal. San Antonio: Harcourt Brace Jovanovich.

\section{Copyrights}

Copyright for this article is retained by the author(s), with first publication rights granted to the journal.

This is an open-access article distributed under the terms and conditions of the Creative Commons Attribution license (http://creativecommons.org/licenses/by/4.0/). 